\title{
Quadrinhos e divulgação científica: compreendendo a ação dos vírus da dengue no organismo humano
}

\section{Comics and scientific dissemination: understanding the action of dengue viruses in the human organism}

\author{
Hylio Laganá Fernandes \\ Universidade Federal de São Carlos - UFSCar, Sorocaba, Brasil ${ }^{1}$ \\ Amanda Karina Loyolla de Carvalho ${ }^{2}$ \\ Estúdio Heavy\&Salsa, Campinas, Brasil
}

\section{Resumo}

O GIBIOzine, revista de histórias em quadrinhos de divulgação científica de Biologia, teve uma edição sobre "Dengue" produzida para veicular informações sobre essa doença, que foi avaliada em escolas, processo que apontou dificuldade dos alunos em entender a dinâmica dos vírus no organismo e sistema imune. A partir dessa constatação foi elaborada uma nova versão da publicação, com objetivo de adequar essas informações. Neste artigo esse processo foi analisado: os textos, antes muito extensos e com termos técnicos, foram alterados num roteiro que privilegia imagens como veículos explicativos e personagens que fornecem informações sucintas, cumprindo melhor o papel de divulgação científica.

Palavras-chave: Histórias em Quadrinhos. Criação. Linguagem. Sistema imune.

\begin{abstract}
GIBIOzine, a comics magazine for scientific dissemination of Biology, had an edition about "Dengue" produced to convey information about this disease, which was evaluated in schools, a process that pointed out students' difficulty for understanding the dynamics of viruses in the organism and the Imune system. Based on this observation, a new version of the comic book was prepared, in order to adapt this information; that process
\end{abstract}

1 Professor Associado do Departamento de Ciencias Humanas e Educação (DCHE) da Universidade Federal de São Carlos. Docente do Programa de pós-graduação de Mestrado em Educação (PPGEd Sorocaba - UFSCar). Email: hyliolafer@gmail.com. ORCiD: https://orcid.org/0000-0003-0922-867X.

${ }^{2}$ Quadrinista do Estúdio Heavy\&Salsa. Rua Manoel José da Fonseca, 471 ap 141 Centro Sorocaba/SP. Fone: (15) 98821 4719. Email: loyollaartes@gmail.com. 
was analyzed in this article: the texts, which were previously very extensive and with technical terms, were changed in a script that privileges images as explanatory vehicles and characters that provide succinct information, better fulfilling the role of scientific dissemination.

Keywords: Comics. Creation. Language. Imune system.

\section{Introdução}

Rama e Vergueiro (2007) entendem as histórias em quadrinhos como arte gráfica sequencial e também como um meio de comunicação mais completo que textos escritos, na medida em que associam linguagens verbais e imagéticas, e (re)afirmam sua grande aceitação entre o público jovem. O potencial de seu uso na divulgação científica, tornando mais acessiveis informações técnicas sobre a ciência, já foi apontado por alguns autores (CARUSO, CARVALHO, SILVEIRA, 2002; DANTON, 2010), assim como sua utilização no ensino tem sido evidenciada em diversos trabalhos (CARUSO, 2002; RAMA, VERGUEIRO, 2007), o que justifica a escolha dessa linguagem com o escopo de produzir um material de DC:

A GIBIOzine (ISSN 1984-610X), produzida pelo grupo de pesquisa "Imagens em Ação"/UFSCar-Sorocaba desde 2007, é uma revista de divulgação científica que utiliza a linguagem dos quadrinhos para divulgação de conteúdos científicos, especialmente na área da Biologia: dai seu nome, na fusão das palavras "GIBI" (em alusão a denominação brasileira para revistas em quadrinhos), com "BIO" (referente a Biologia), tendo o sufixo "zine" associado a sua produção, nos moldes do fanzine (MAGALHÃES, 2003; ANDRAUS; SANTOS, 2010). A produção de histórias em quadrinhos do GIBIOzine conta com colaboradores docentes e pesquisadores da área dos quadrinhos, estudantes de graduação de diversos cursos e também crianças e jovens em geral. O resultado é uma revista com amplo espectro de estilos gráficos e narrativos.

$\mathrm{O}$ processo de produção do material para o GIBIOzine acontece de diversas formas. No ensino superior, especificamente Licenciatura em Ciências Biológicas da UFSCar, a produção da história em quadrinhos ocorre como parte de um processo de formação de professores; no ensino básico, em Escolas Estaduais, como processos 
educativos e/ou avaliativos de propostas desenvolvidas junto aos professores em exercício; por fim, há colaboração de trabalhos autônomos realizados por autores/pesquisadores com interesse na área. Ela é apresentada em uma plataforma digital (gibiozine.wix.com/gibiozine) e foi produzida no formato impresso até 2017, com tiragens de 1.000 a 3.000 exemplares; a aceitação da revista impressa, nos espaços em que é gratuitamente distribuída e encontros acadêmicos em que tem sido apresentada, tem sido muito boa, o que sugere ser um formato interessante para divulgação científica (não há ainda dados sistematizados referentes à versão digital).

Será enfocada neste trabalho a produção de um número especial, o GIBIOzine\#13 temático sobre a Dengue, que foi produzido e distribuido em escolas de Sorocaba/SP, por ocasião de um forte surto de dengue (SOROCABA, 2015). Para Guimarães e Giordan (2011), a aprendizagem é sinônimo de melhoria social, haja vista a apropriação de conhecimentos capazes de (re)significação da realidade, que alinhado ao pensamento com Cachapuz (2005), segundo o qual as ideias iniciais do aluno precisam ser consideradas constantemente e não devem permanecer isoladas, mas articuladas em problemáticas do seu interesse, resulta num cenário que favorece um ensino contextualizado para uma aprendizagem significativa.

A Dengue é uma doença viral com um quadro clínico amplo, variando de forma assintomática até formas graves e letais; não há, até o presente momento, nenhuma vacina ou outra forma clínica de combater o virus, dependendo a cura da resposta imunológica do organismo - com o complicante de que medicação errada pode piorar o quadro . Existem quatro sorotipos desse vírus, com propriedades antigênicas diferentes; contudo, todos os sorotipos podem causar as duas formas clinicas da doença, que são a Dengue Clássica e Dengue Hemorrágica (COSTA; SANTOS; BARBOSA, 2009): a melhor opção, em qualquer caso é, portanto, a profilaxia. Dado esse contexto, decidiuse fazer um material de divulgação cientifica abordando o tema "dengue" de maneira a ser utilizado por estudantes de ensino básico, mas que também chegasse à comunidade desses estudantes, uma vez que o problema transpassa os muros da escola; assim, foi elaborada uma história utilizando linguagem das histórias em quadrinhos para disponibilizar informações sobre a doença, proporcionando oportunidade de ações 
preventivas conscientes - e inclusive a possibilidade de soluções criativas pela comunidade.

A opção pela história em quadrinhos, como já apontado, deveu-se a facilidade comunicativa que, como já apresentado, essa linguagem favorece, especialmente entre o público jovem; a elaboração do roteiro envolveu um minucioso trabalho de pesquisa, seja das informações técnicas sobre a doença, seja na elaboração dos personagens que comporiam a história (os personagens pertencem a três domínios: universo celular, mosquitos e humanos), assim como relatos de pessoas da comunidade acometidas pela doença.

\section{1 - Lendo o GIBIOzine\#dengue na escola}

O GIBIOzine foi distribuído em 4 escolas (número limitado pela tiragem que tínhamos disponivel), em diferentes bairros de Sorocaba, onde havia focos mais intensos da doença. Em uma dessas escolas foi feito um estudo mais aprofundado, visando avaliar sua aceitação como material didático pelos jovens estudantes, assim como se as informações nele contidas estavam sendo compreendidas por esses jovens (KOGA et alii, 2018). Após leitura e discussão do GIBIOzine com algumas turmas, foi respondido um questionário sobre a opinião dos estudantes abordando aspectos sobre conteúdo e forma da revista, visando responder três aspectos: o primeiro correspondia a conteúdos sobre a dengue; o segundo visava saber a opinião estética sobre o material; por fim, uma última questão aberta para que os alunos apresentassem opiniões e sugestões para melhoria do material. Foi feita uma análise quantitativa e análise do conteúdo dos textos escritos (BARDIN, 2009).

Os resultados apontaram que o GIBIOzine esclareceu dúvidas sobre a dengue para a maioria dos alunos ( 85 alunos, $90,4 \%$ ) e que eles gostaram da revista ( 87 alunos, $92,5 \%$ ), indicando que a revista foi bem recebida e colaborou no entendimento de aspectos da epidemia. Para análise das questões dissertativas foi feita análise de conteúdo (BARDIN, 2009), de onde emergiram 4 categorias: aspectos estéticos, aspectos instrucionais, linguagem e enredo. Na categoria linguagem, que nos interessa 
para o presente trabalho, diversos estudantes apontam "melhorar a linguagem", referindo-se a dificuldade na compreensão, especialmente de trechos das ações do sistema imunológico e transcrição dos vírus (KOGA et al, 2018). A partir desses resultados ficou claro que essa parte deveria ser melhorada no quesito comunicacional, uma vez que não estavam sendo bem compreendidos os conceitos científicos envolvidos. Foi elaborada então uma segunda versão, também pela artista e bióloga Amanda Loyolla, visando facilitar a compreensão dos conceitos e dinâmicas apresentados referentes ao sistema imunológico e ações dos vírus no organismo humano.

A seguir são apresentadas as discussões sobre as duas obras, chamadas aqui "primeira versão" para a primeira história em quadrinhos produzida, em 2015 e "segunda versão" para a segunda, reescrita em 2017, sendo abordados aspectos da recriação da história, e analisados os elementos transformados.

\section{2 - Processo criativo e divulgação científica}

O processo de recriação, pretendendo uma melhor comunicação sobre as informações dos conceitos apresentados, teve uma evidente (e até certo ponto óbvia) mudança no que se refere ao número de páginas: eram nove páginas na primeira versão e passaram a ser dezessete páginas na segunda versão. $\mathrm{O}$ aumento no número de páginas permite inferir que houve um maior detalhamento das informações veiculadas; mas para além disso, também possibilitou uma narrativa mais clara e um incremento nas informações (visuais e textuais), possibilitando uma melhor compreensão dos conceitos e dinâmicas.

Segundo o artigo de La Pastina e Duarte (2008), para criarmos um desenho precisamos desenvolver não só o gesto gráfico, mas também a memória visual formando um 'modelo interno' do que se pretende fazer. Por consequência disso, quanto maior o domínio que se tem sobre um determinado assunto mais fácil se torna o processo de criar o modelo interno e comunicá-lo externamente por meio de imagens desenhadas. A diferença entre ter ou não esse modelo interno construído fez a diferença no processo de roteirização das duas versões do quadrinho sobre dengue. 
Para criar o roteiro inicial da primeira versão, que se refere à parte interna do corpo humano, foi necessária muita pesquisa da área de imunologia, procurando artigos que falassem sobre estudos de resposta do corpo ao virus da dengue e como o vírus age ao ser inoculado na corrente sanguínea humana. $O$ fato da roteirista estar aprendendo sobre o assunto ao mesmo tempo que tentava explicá-lo, associado à limitação do tempo para finalizar a obra, fez com que na primeira versão fossem usados apenas seu conhecimento gráfico de desenho e sua criatividade, sem um tempo de amadurecimento e análise para comunicar o que se havia encontrado como resultado das pesquisas. A construção do roteiro da primeira versão foi uma tentativa de resumir algumas informações centrais, compreendidas graças a sua formação como bióloga, mas sem que a roteirista tivesse incorporado efetivamente o conteúdo para poder realizar uma sintese compreensivel ao público leigo. Portanto, a falta de dominio sobre o assunto foi claramente refletida no entendimento dos alunos ao lerem o gibi. A falácia ocorrida nesse caso foi a roteirista ter base para entender os artigos e supor que os alunos teriam a mesma capacidade de compreensão ao ler o quadrinho.

A função de uma história em quadrinhos é comunicar algo, contar uma história na linguagem dual de imagens e textos relacionados (MENDES, 1990), característica dessa arte. Se o leitor não consegue compreendê-la então a função não foi cumprida. A proposta dessa produção - informar de maneira clara e simples como o corpo reage ao vírus e como o vírus ataca o corpo - não foi atingida: os leitores acabaram não entendendo o conteúdo referente aos processos imunológicos. Em parte isso se deu porque os leitores não tinham informações técnicas para sua compreensão, comprometendo assim a fluidez da narrativa, porém também porque nessa primeira versão o vírus quase não aparece e as células de defesa têm balões com textos explicativos relativamente extensos e pouca informação icônica; ainda, as personagens se inserem em um universo (o interior do corpo humano) que está mal apresentado ou não está devidamente contextualizado no desenho. Um exemplo claro para tal encontrase na página que inicia com a caixa de texto "enquanto isso dentro do corpo..." (figura 1): as imagens que se seguem não mostram o que é um linfonodo, nem para que ele serve ou onde ele se situa no organismo humano. Não há como o leitor adivinhar o que 
é, se não tiver esse conhecimento prévio. Ainda, notou-se que o roteiro da primeira versão estava demasiadamente sustentado pelos balões e caixas de texto, sendo a imagem apenas ilustração simples para apoio dos textos (figura 1): essa foi uma fragilidade comunicativa identificada a ser superada na segunda versão.

Figura 1 - Apresentação do linfonodo, "paisagens" do interior do corpo humano e células de defesa.

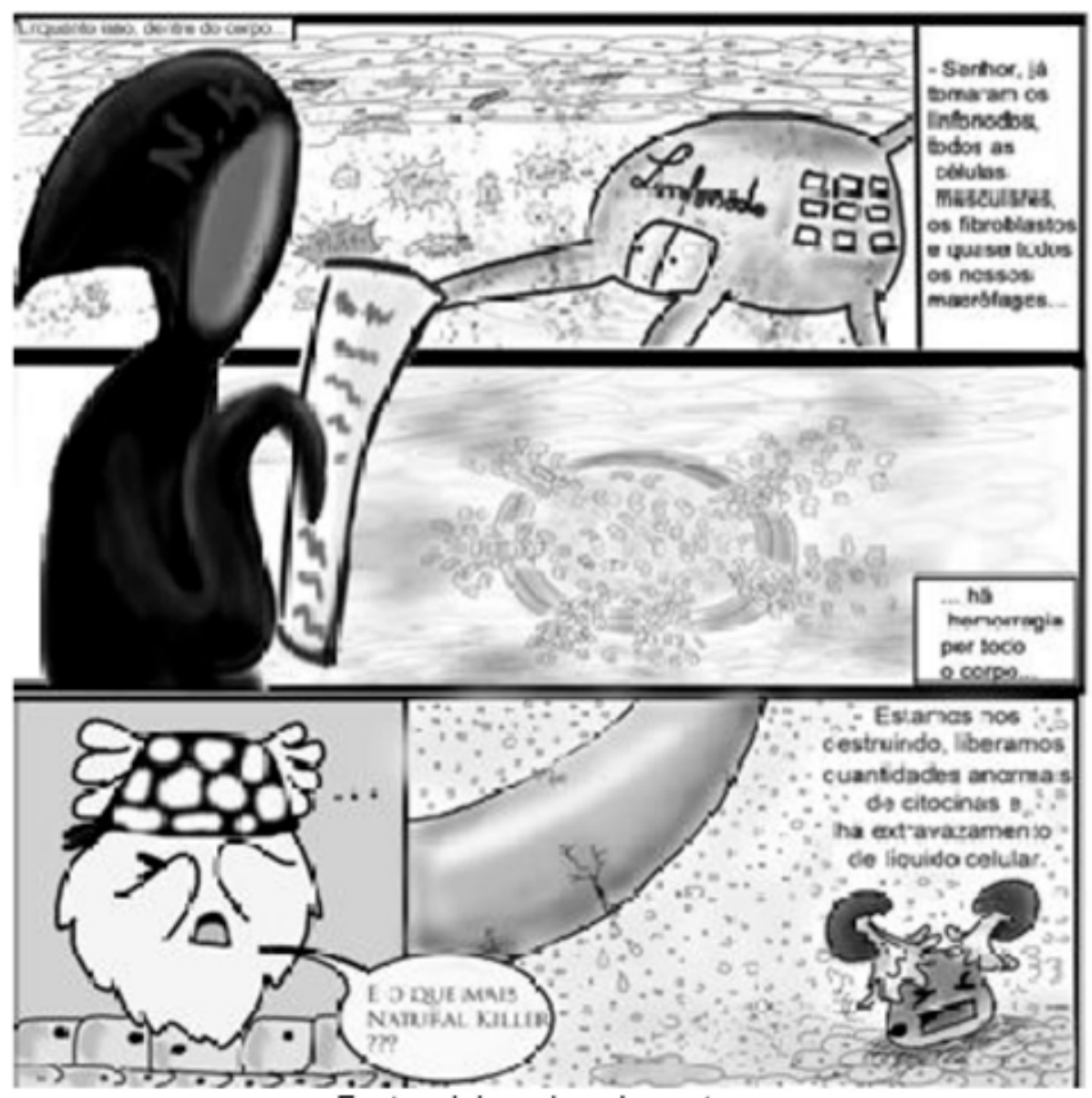

Fonte: elaborado pelos autores

Outro ponto notável nesse processo de reelaboração diz respeito aos personagens que vão compor a história: as células de defesa do corpo humano e vírus da dengue. Com relação aos vírus, na primeira versão são apresentados com diferentes "faces", dentro de um modelo básico de "faces ameaçadoras" (figura 2A), enquanto que na segunda versão padronizou-se para um único tipo, eleito entre os primeiros, apenas com pequenas variações individuais (figura $2 \mathrm{~B}$ ). 
Figura 2: Representação dos virus da dengue: na primeira versão (A) note-se as seis faces com diferentes variações, tendo em comum a boca aberta com dentes pontiagudos, para dar a aparência ameaçadora; na segunda versão (B) padronizou-se um modelo para o virus mas mantiveram-se pequenas variações individuais (o virus que fala tem um terceiro olho)

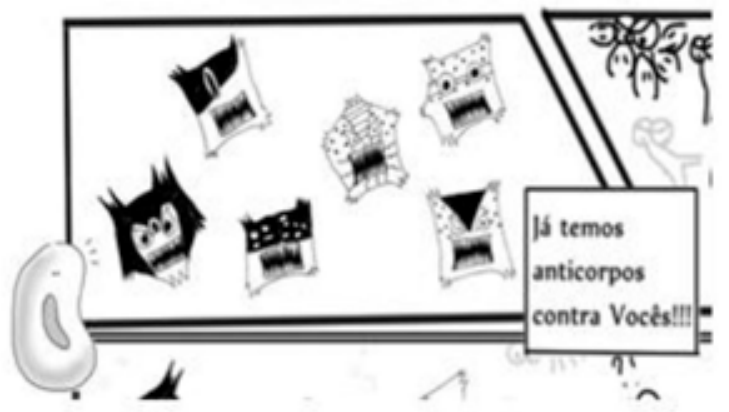

A

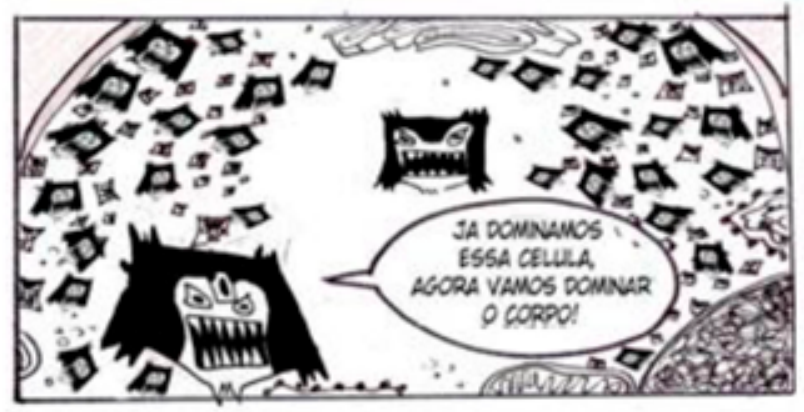

B

Fonte: elaborado pelos autores

Embora nenhum dos alunos leitores participantes da pesquisa tenha levantado alguma objeção ou comentário sobre as faces dos vírus, associando aos sorotipos (há quatro formas virulentas, todas já identificadas no Brasil), tal mudança se deu a partir de discussões internas da equipe de produção: desenhos com faces diferentes podem gerar confusão se forem relacionados aos sorotipos de vírus da dengue conhecidos. Para deixar claro que existem diferentes tipos de virus, mas que em cada infestação apenas um desses tipos invade o organismo humano, utilizou-se na segunda versão um único modelo, com variações de pequenos detalhes individuais.

Com relação às células do sistema imunológico do corpo (natural killer, macrófago, linfócito $B, T C D 8$ e TCD4), na primeira versão elas aparecem simplesmente, sem maiores explicações, cabendo ao leitor a dedução de que se tratam de distintas células de defesa e suas funções; na segunda versão elas são apresentadas individualmente por um macrófago narrador, anunciando que cada qual cumpre diferentes funções (figura 3). Embora, tampouco aqui nenhum aluno colaborador tenha feito nenhum apontamento na pesquisa anterior, ao fazer a apresentação sistemática dessas células fica muito mais claro para o leitor leigo que há diferentes células que agem em conjunto, com suas respectivas especificidades, nas ações de defesa do sistema imunológico no combate aos vírus. 
Figura 3 - Macrófago (célula de defesa humana) apresenta as demais células de defesa, logo no início da história. Na sequência, cada uma das células, conforme vai aparecendo no roteiro, apresenta suas funções específicas.

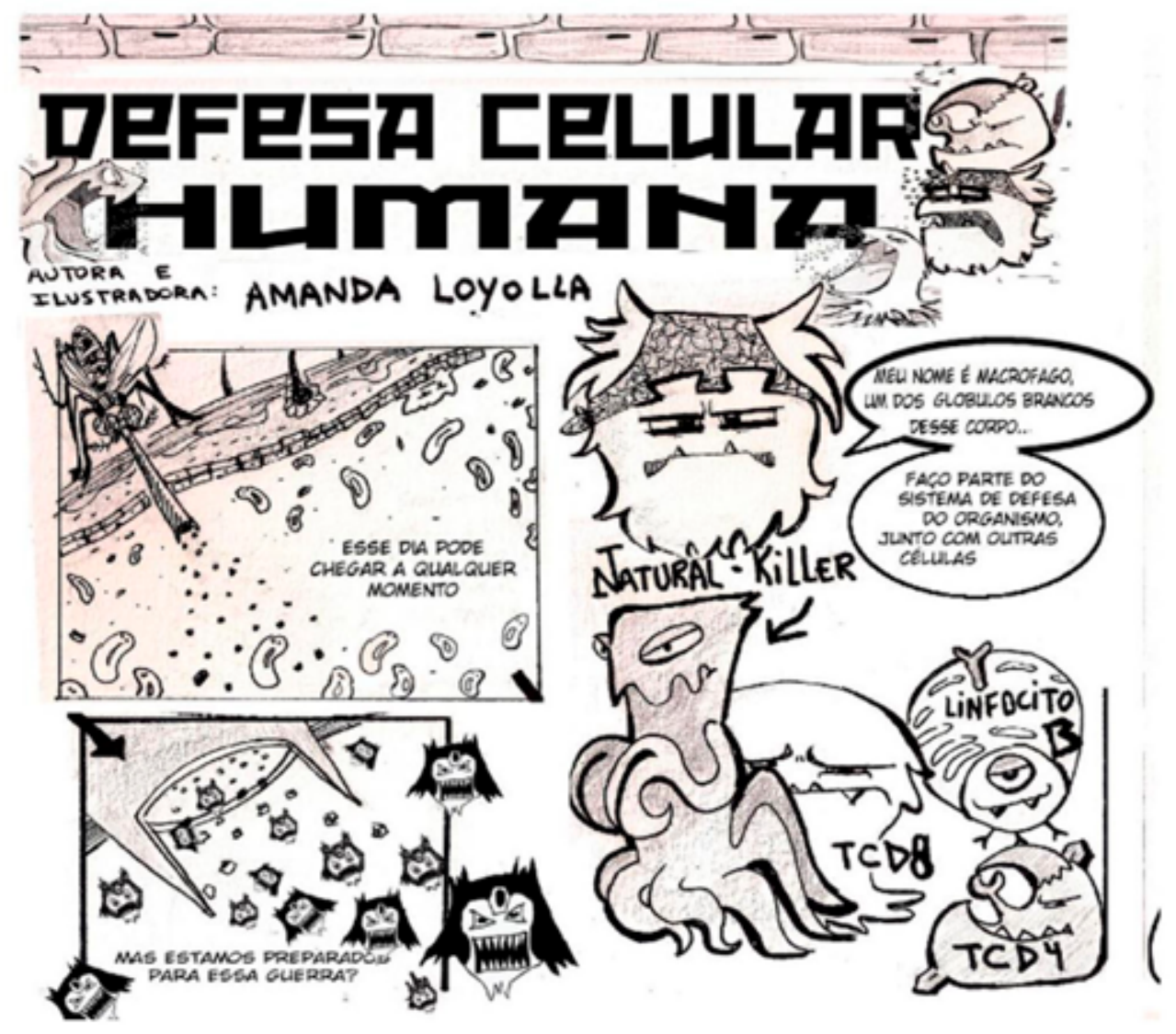

Fonte: elaborado pelos autores

Ao analisar a primeira versão foi possivel perceber que diversos conceitos e/ou dinâmicas complexas foram apresentadas de modo bastante sintético, inclusive envolvendo termos técnicos que não são familiares para pessoas fora do universo da Biologia: isso acarreta, obviamente, uma dificuldade na compreensão da informação pretendida, conforme apontaram os alunos-colaboradores da escola. O melhor exemplo desse aspecto, que foi amplamente levantado pelos alunos, encontra-se na abordagem sobre a replicação viral: na primeira versão a explicação se resume a praticamente um quadrinho (figura 4). 
Figura 4 - Quadrinho explicando a replicação viral na primeira versão. Toda a explicação está condensada em um balão com esquemas simples.

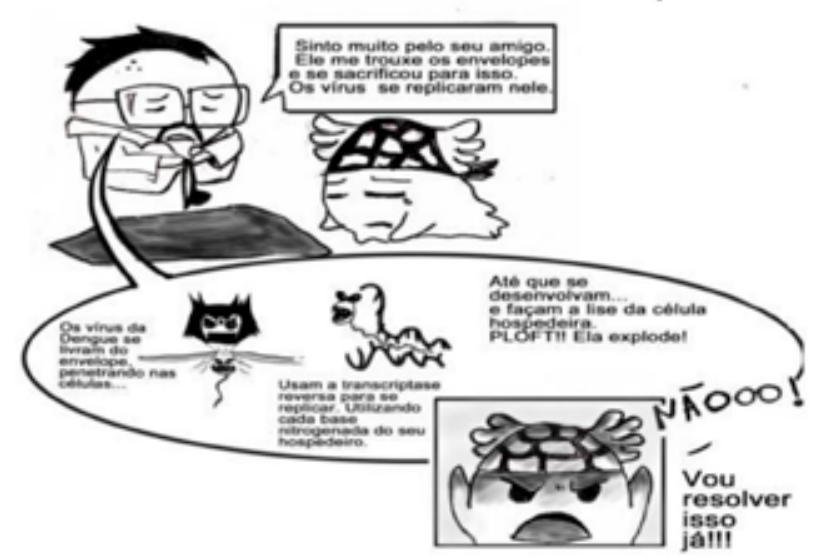

Fonte: elaborado pelos autores

Note-se que além do termo "replicação" (que é desconhecido pelo público leigo, mas considera-se que deverá ser compreendido a partir dessa leitura), são apresentados termos com sentidos desconhecidos, como "envelope" (termo técnico que se refere à cápsula que envolve o material genético dos vírus), "transcriptase reversa" (uma enzima específica), "base nitrogenada" (moléculas que entram na composição dos ácidos nucleicos DNA e RNA) e "lise", que é o rompimento/morte da célula. A comunicação imagética apresenta-se bastante esquemática e as informações textuais são insuficientes para compreensão do que ocorreu para os vírus se replicarem (reproduzirem), utilizando o material e processos metabólicos da célula. Essas informações, bastante elementares para alguém que estudou biologia, podem ser indecifráveis para quem não conhece os conceitos envolvidos, acarretando a não transmissão de informações - e, portanto, em um fracasso da divulgação científica pretendida.

$\mathrm{Na}$ segunda versão essa parte referente a replicação viral desdobra-se em uma narrativa de cinco páginas (figura 5). Invertendo a narrativa, nesse momento a história em quadrinhos lança o leitor para a perspectiva dos virus. Começa com um linfócito $B$ alertando outra célula que os vírus "Parecem Aliens" (numa alusão ao "oitavo passageiro" do filme clássico "Aliens"), mas que também anuncia ao leitor que os vírus são muito diferentes das células humanas - estranhos parasitas que matam; em seguida muda 0 
foco para um vírus, tomado em primeiro plano, que passa a narrar seu próprio destino incerto e desconhecido ao entrar na célula hospedeira, constatar (um pouco assombrado) que em sua "essência" é apenas uma fita de RNA, e por fim decidir "escravizar" os elementos celulares para sua replicação. O processo realizado pelo ribossomo de decodificação das informações do código genético na correlação com aminoácidos e consequente formação de uma proteína são mostrados em detalhes, deixando claro que as proteínas originárias compõem novos vírus, explicando com mais detalhes a origem dos virus. Por fim mostram o ribossomo exausto, "montando" virus, e dezenas de vírus que já dominaram completamente a célula e se preparam para invadir outras.

Figura 5 - Sequência da segunda versão na qual se explica, passo a passo, o processo de replicação viral dentro da célula humana
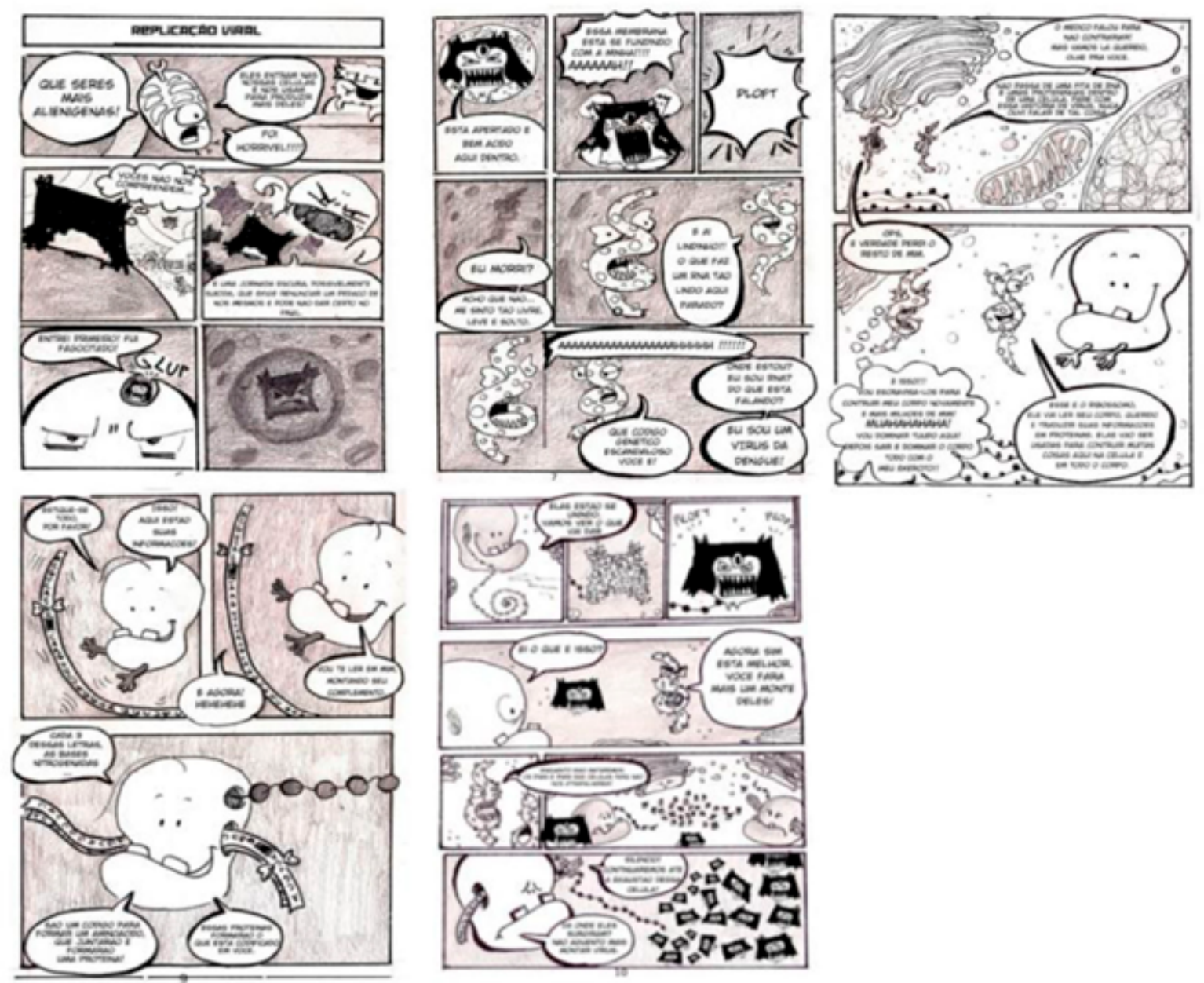

Fonte: elaborado pelos autores 
Do ponto de vista científico essa explicação ainda está bastante simplificada no que diz respeito à formação das proteínas dos envelopes dos vírus, e está inclusive incompleta ao não apresentar o processo de replicação do RNA-viral que vai preencher tais envelopes; contudo fornece ao leitor leigo informações suficientes para compreender que os virus se apropriam dos processos metabólicos celulares para sua reprodução, exaurindo a célula e levando-a ao colapso. Tal informação é importante para compreensão do processo de infestação viral e suas consequências nas células (e no organismo), mesmo não estando descritos detalhes como o papel da enzima "transcriptase reversa", que vai atuar na replicação do RNA, nem especificações na transcrição gênica e formação de proteinas. A segunda versão cobre essa lacuna, em termos de informações necessárias para compreensão do processo de replicação viral, que havia ficado na ultra-simplificada explicação na primeira versão, apontada pelos alunos-colaboradores na pesquisa anterior como de difícil compreensão.

Ao fazer a segunda versão da história em quadrinhos, não havia mais dúvidas quanto à parte da imunologia a ser explicada, uma vez que o conteúdo necessário já havia sido exaustivamente pesquisado e compreendido com clareza. Houve tempo para maturação e processamento dos dados pesquisados e analisados. Como consequência, foi possivel focar na forma de comunicação com os alunos, na diagramação e em como simplificar o assunto. Em vez de contar com textos escritos aos leitores, foram selecionadas partes principais e detalhadas com imagens para que a comunicação visual, icônica, tivesse um papel mais ativo. Também nessa segunda versão o universo em que as personagens (vírus e células humanas) interagem, assim como as próprias personagens, foi mais bem trabalhado.

Desse modo, foi melhorada a criação imagética e narrativa, superando o foco informativo e bastante sintético que a primeira versão apresentava. Porém, vale destacar que se houvesse oportunidade para uma terceira criação de roteiro, novamente haveria mudanças e o processo continuaria a amadurecer, pois ainda há a necessidade de diluir ainda mais a informação científica na história, mesmo isso resultando em um aumento do número de páginas. A segunda versão se preocupou em mostrar por meio de imagens o que acontece dentro do corpo, fazendo da escrita o complemento do que está 
mostrando; porém alguns balões ainda estão muito cheios de informação textuais, que poderiam ser atenuadas com referenciais imagéticos. Quanto mais "diluído" o conteúdo científico ao longo da narrativa, mais simplificado o texto em seus termos técnicos e mais informativa as representações imagéticas, melhor para o leitor processar a informação que está sendo pretendida.

Analisando a primeira versão foi possivel entender que quando o foco da história foi passar direta e objetivamente o conteúdo, nem o interesse nem a compreensão dos leitores/alunos foram bons. Quando eles se depararam com uma história mais romantizada, na qual as informações científicas estão presentes, embutidos numa história, entendê-la se tornou mais agradável e palatável.

\section{Considerações}

A proposta da utilização de histórias em quadrinhos para a divulgação científica já tem sido apontada por diversos autores (CARUSO, CARVALHO, SILVEIRA, 2002; DANTON, 2010), pois conjuga o potencial comunicativo dos quadrinhos e aceitação dessa linguagem entre o público jovem (RAMA; VERGUEIRO, 2007). A transposição das informações cientificas para uma linguagem simples, compreensivel por uma população leiga, contudo, não é uma tarefa trivial. Neste trabalho foi analisado um processo que envolveu: a produção de uma história em quadrinhos com objetivos de divulgação científica sobre a dengue, a avaliação dessa narrativa por leitores leigos quanto ao quesito compreensão das informações veiculadas, e reelaboração da narrativa a partir das dificuldades de compreensão identificadas por esses leitores, visando superá-las; foram comparadas a narrativa produzida inicialmente com aquela reelaborada após a leitura, e os resultados apontam elementos importantes para se pensar a divulgação de informações científicas.

Inicialmente, identifica-se que o número de páginas aumentou significativamente: de sete para dezessete páginas. A dinâmica dos vírus da dengue no organismo humano, e a resposta imunológica a essa proliferação, constituem um tema bastante complexo (inclusive com diversos pontos para os quais ainda não há informações 
científicas/técnicas plenamente elucidadas). Parece claro que, para contextualizar minimamente tantas informações, sejam necessárias mais do que sete páginas.

Extrapolando essa medida quantitativa, que em verdade pouco diz, a análise das sequências mostra que, em termos qualitativos: primeiramente, deve haver um cuidado com a apresentação dos conceitos/termos científicos, que podem aparentar ser bastante claros para a roteirista/desenhista da história em quadrinhos (que no caso tem formação em ciências biológicas), mas não o são para o público leigo. Esse é um entrave amplamente discutido no campo da divulgação científica, ou seja, o de que a linguagem utilizada não pode ser demasiado técnica, mas simplificada para efetivar a comunicação com o leitor leigo. O primeiro grande desafio do divulgador científico reside nessa transposição.

Em segundo lugar, e nesse ponto entramos no universo específico das histórias em quadrinhos, ficou evidente que a utilização de imagens para apresentar os temas científicos abordados tem vantagens sobre informações verbais/escritas: inclusive, o aumento do número de páginas foi devido à criação de sequências que explicam os processos por meio de narrativas visuais, que demandam espaço para serem apresentadas. Um texto explicando a "replicação viral" pode ser breve, mas incompreensivel devido à quantidade de informações que demanda para sua decodificação plena; uma sequência ilustrada sobre essa replicação apresenta iconicamente esse conteúdo, permitindo que o leitor compreenda o processo mesmo sem conhecer exatamente e a fundo as especificações técnicas envolvidas.

Ainda, emerge o fato de que para criar uma narrativa que mantenha a atenção e interesse do leitor alguns elementos devem ter uma atenção especial, como a devida apresentação das personagens da trama, a caracterização correta e compreensivel do universo onde se desenvolve a narrativa e a precisão dos conceitos apresentados - ainda que obviamente se conceda uma "licença poética", por exemplo, ao humanizar células e virus e atribuir a estes faces, expressões e emoções. Em outras palavras, ainda que se coloque uma face e um comportamento autônomo para uma célula, como se ela fosse um individuo pensante, é fundamental que o papel que essa célula exerce no processo apresentado fique muito bem definido, assim como o contexto em que se passa a 
narrativa, para permitir ao leitor elaborar a construção dos conceitos envolvidos. Por fim, mas não menos importante, a necessidade de criar uma narrativa que seja interessante e segure a atenção do leitor: uma narrativa que se preocupe em contar uma história, de preferência envolvente e dinâmica, na qual conceitos científicos apareçam naturalmente, e não apresentar conceitos científicos com uma narrativa para meramente sustentá-los.

\section{Agradecimentos e apoios}

Pró-reitoria de Extensão ProEx/UFSCar / Capes - PIBID

\section{Referências}

ANDRAUS, G.; SANTOS, N. E. Dos zines aos biograficzines: compartilhar narrativas de vida e formação com imagens, criatividade e autoria. In: MUNIZ, C. (Org.) Fanzines: autoria, subjetividade e invenção de si. Fortaleza: Edições UFC, 2010.

BARDIN, L. Análise de conteúdo. Lisboa, Portugal: Edições 70, LDA, 2009.

BARRETO, M. L.; TEIXEIRA, M G. Dengue no Brasil: Situação epidemiológica e contribuições para uma agenda de pesquisa. Estudos Avançados. Brasilia: v. 22, n.64, p. 53- 72, 2008.

CACHAPUZ, A. A necessária renovação do ensino das ciências. São Paulo: Cortez, 2005..

CARUSO, Francisco; CARVALHO, Mirian de. SILVEIRA, Maria Cristina. Uma proposta de ensino e divulgação de ciências através dos quadrinhos. Ciência \& Sociedade, Rio de Janeiro, Centro Brasileiro de Pesquisas Físicas (CBPF), n. 8, 2002. Disponivel em: http://cbpfindex.cbpf.br/publication pdfs/cs00802.2006 12081029 32.pdf. Acesso em: 10 abr. 2020.

COSTA, C.A.; SANTOS, I.G.C.; BARBOSA, M.G. Deteç̧ão e tipagem de virus em Aedes aegypti (Díptera: Culicidae) na cidade de Manaus, Estado do Amazonas. Revista da Sociedade Brasileira de Medicina Tropical, v. 42, n. 6, p. 677-681, nov.-dez. 2009.

DANTON, G. (OLIVEIRA, I. C. A). A divulgação cientifica nos quadrinhos: análise do caso Watchmen. Dissertação (Mestrado) da Universidade Metodista de São Paulo. São Paulo: 1997. Disponivel em: http://virtualbooks.terra.com.br/livros online/gian/01.htm. Acesso em: 10 abr. 2020.

GUIMARÃES, Yara Araújo Ferreira; GIORDAN, Marcelo. Instrumento para construção e validação de sequências didáticas em um curso a distância de formação continuada de professores. In: ENCONTRO NACIONAL DE PESQUISA EM EDUCAÇÃO EM CIÊNCIAS, 8, 
Campinas, 2011. Atas. Campinas: Associação Brasileira de Pesquisa em Educação em Ciências, 2011. Disponivel em: http://abrapecnet.org.br/atas enpec/viiienpec/resumos/R0875-2.html. Acesso em: 28 mar. 2020.

KOGA, M. L.; COSTA, S. R. F.; FERNANDES, H. L. . Histórias em quadrinhos no ensino de biologia: um enfoque sobre a dengue numa escola pública no interior de São Paulo. TEMPORIS [AÇẪO], v. 17, p. 43-55, 2018.

LA PASTINA, C. C.; DUARTE, M. L. B. Reflexões sobre desenho infantil, memória e percepção. Contra Pontos, Itajai, v. 8, n. 1, p.113-128, jan./abr. 2008.

MAGALHÃES, Henrique. O rebuliço apaixonante dos fanzines. João Pessoa: Marca de Fantasia, 2003.

MENDES, M.R.S. El papel educativo de los comics infantiles: análise de los espereotipos Sexuales. Tese (Douturado em Ciencias de la Información) - Facultad de Ciencias de la Información, Universidad Autónoma de Barcelona, Barcelona, 1990.

RAMA, A.; VERGUEIRO, W. (orgs.). Como usar as histórias em quadrinhos na sala de aula. 3.ed. São Paulo: Ed Contexto, 2007.

SOROCABA. Secretaria da Saúde. Dengue e Chikungunya. Boletim Epidemiológico, Sorocaba, v. 03 , n. 10,2015 . Disponivel em: http://www.sorocaba.sp.gov.br/dengue/wpcontent/uploads/sites/29/2015/04/boletim 10.pdf. Acesso em: 27 mar. 2020. 